\title{
ANALISIS KINERJA KEUANGAN DENGAN METODE RADAR PADA PT SEMEN BATURAJA (PERSERO) TBK
}

\author{
Siska Mardiana ${ }^{1}$ \\ R. Deni Muhammad Danial ${ }^{2}$ \\ Erry Sunarya ${ }^{3}$
}

\author{
Fakultas Ilmu Administrasi dan Humaniora Universitas Muhammadiyah \\ Sukabumi, Jawa Barat, Indonesia ${ }^{1,2,3}$ \\ Email : Siskamardiana334@gmail.com ${ }^{1}$, \\ rdmdanial043@ummi.ac.id², \\ errysoen@gmail.com ${ }^{3}$
}

\begin{abstract}
The purpose of this study is to assess the financial performance of PT Semen Baturaja (Persero) Tbk by comparing the performance of PT Semen Baturaja (Persero) Tbk in several similar companies that have been listed on the Indonesia Stock Exchange. The data used are financial statement data of PT Indocement Tunggal Prakarsa Tbk, PT Semen Baturaja Persero Tbk and PT Holcim Indonesia Tbk for the period 2015-2017. The research method used is descriptive with quantitative data. The analysis technique used with the radar method. Radar analysis includes 5 ratios, namely profitability, productivity, asset utility, stability and growth potential. The results showed that the best profitability ratio of PT Semen Baturaja (Persero) Tbk, from the best productivity ratio of PT Holcim Indonesia Tbk, was seen from the best utility ratio of PT Indocement Tunggal Prakarsa Tbk, on the stability ratio of PT Holcim Indonesia Tbk and on the best growth potential of PT Semen Baturaja (Persero) Tbk.
\end{abstract}

Keywords : Financial Performance, Radar Method.

\begin{abstract}
ABSTRAK
Tujuan penelitian ini adalah untuk menilai kinerja keuangan PT Semen Baturaja (Persero) Tbk dengan membandingkan kinerja PT Semen Baturaja (Persero) Tbk dalam beberapa perusahaan yang sejenis yang telah terdaftar di Bursa Efek Indonesia. Data yang digunakan yaitu data laporan keuangan PT Indocement Tunggal Prakarsa Tbk, PT Semen Baturaja (Persero) Tbk dan PT Holcim Indonesia Tbk periode 2015-2017. Metode penelitian yang digunakan yaitu deskriptif dengan data kuantitatif. Teknik analisa yang digunakan dengan metode radar. Analisis radar mencakup 5 rasio yaitu rasio profitabilitas, produktivitas, utilitas aktiva, stabilitas dan potensi pertumbuhan. Hasil penelitian menunjukan bahwa dilihat dari rasio profitabilitas PT Semen Baturaja (Persero) Tbk yang paling bagus, dari rasio produktivitas PT Holcim Indonesia Tbk paling bagus, dilihat dari rasio utilitas aktiva PT Indocement Tunggal Prakarsa Tbk yang paling bagus, pada rasio stabilitas PT Holcim Indonesia Tbk dan pada potensi pertumbuhan paling bagus PT Semen Baturaja (Persero) Tbk.
\end{abstract}

\section{Kata Kunci : Kinerja Keuangan, Metode Radar}




\section{PENDAHULUAN}

Seiring dengan kemajuan teknologi dan perkembangan informasi dunia usaha saat ini telah mengalami banyak perkembangan. Hal ini menyebabkan timbulnya kompetisi usaha yang semakin ketat. Setiap perusahaan tentunya memiliki tujuan dalam memulai usaha dengan menghasilkan laba semaksimal mungkin dari kegiatan usaha dengan cara membuat suatu inovasi produk terbaru yang dapat menarik perhatian dan memenangkan persaingan bisnis sehingga konsumen dapat membeli dan menggunakan. Dalam persaingan yang semakin ketat ini perusahaan menuntut target yang lebih efesien dalam mengelola kinerja yang lebih berkompeten.

Pengukuran kinerja keuangan merupakan salah satu peran penting dalam proses perencanaan. Melalui pengukuran kinerja keuangan perusahaan dapat mengetahui perkembangan kinerja keuangan perusahaan yang dapat diperoleh melalui analisis terhadap data keuangan perusahaan yang tersusun dalam laporan keuangan. Perusahaan dapat meningkatkan kinerja keuangan dan memenangkan persaingan dalam dunia bisnis. Penilaian atas kinerja keuangan perusahan dapat ditentukan baik atau buruknya dalam pencapaian kinerja. Dalam pengukuran kinerja tentunya terdapat suatu ukuran yang dapat dijadikan suatu analisis untuk melakukan suatu perbandingan. Ukuran perbandingan yang biasa dipakai untuk mengukur kinerja keuangan yaitu pada umumnya perusahaan menggunakan input laporan keuangan dengan menggunakan rasio-rasio keuangan. Analisis kinerja keuangan dapat dilakukan dengan berbagai macam metode analisis salah satunya dengan menggunakan analisis metode radar. Analisa radar merupakan 
penyempurnaan dari analisa rasio-rasio keuangan sebelumnya karena analisis radar memiliki rasio produktivitas dan diagram yang tidak dimiliki oleh analisis rasio keuangan lainnya. Metode radar dikembangkan oleh APO (Asia Productivity Organization) yang berpusat di Tokyo. Tujuan analisa rasio radar adalah memberikan gambaran tentang posisi keuangan perusahaan dan perkembangannya.

Dengan demikian pengukuran kinerja keuangan perusahaan sangat penting dalam keberlangsungan hidup perusahaan untuk mengetahui kondisi keuangan perusahaan dalam melakukan penilaian terhadap kinerja. Berdasarkan latar belakang dan identifikasi masalah yang telah dijabarkan diatas, maka masalah dalam penelitian ini sebagai berikut Bagaimana kinerja keuangan pada PT Semen Baturaja (Persero) Tbk periode 2015 sampai 2017 dengan metode radar? Sesuai dengan rumusan masalah maka tujuan penelitian ini adalah :Untuk mengetahui kinerja keuangan pada PT Semen Baturaja (Persero) Tbk periode 2015 sampai 2017 dengan metode radar.

Tinjauan pustaka. Sutrisno (2012:3) Menyatakan bahwa : Manajemen Keuangan atau sering disebut pembelanjaan dapat diartikan sebagai semua aktivitas perusahaan yang berhubungan dengan usaha-usaha mendapatkan dana perusahaan dengan biaya murah serta untuk menggunakan dan mengalokasikan dana tersebut secara efisien.

Laporan keuangan merupakan catatan informasi yang menyangkut posisi keuangan dan kinerja suatu perusahaan. Irham (2014:141) "Laporan keuangan merupakan suatu informasi yang menggambarkan kondisi keuangan suatu 
perusahaan, dan lebih jauh informasi tersebut dapat dijadikan sebagai gambaran kinerja keuangan perusahaan tersebut".

Tujuan lapoan keuangan adalah untuk menyediakan informasi yang menyangkut posisi keuangan, kinerja serta posisi keuangan suatu perusahaan yang bermanfaat bagi sebagian besar pemakai dalam pengambilan keputusan. Informasi mengenai posisi keuangan, kinerja dan perubahan posisi keuangan digunakan untuk evaluasi perusahaan dalam menghasilkan kas dan waktu serta kepastian hasil tersebut. Menurut Farid dan Siswanto (2011:2) "Laporan keuangan merupakan informasi yang diharapkan mampu memberikan bantuan kepada pengguna untuk membuat keputusan ekonomi yang bersifat finansial".

Kinerja keuangan sangat berpengaruh pada keadaan suatu perusahaan dimasa yang akan datang dan juga diperlukan untuk menilai perubahan potensial sumber daya ekonomi yang mungkin dikendalikan dimasa depan dan untuk memprediksi kapasitas produksi dari sumber daya yang ada. Fahmi (2012:239) "Kinerja keuangan adalah suatu analisis yang dilakukan untuk melihat sejauh mana suatu perusahaan telah melaksanakan dengan menggunakan aturan-aturan pelaksanaan keuangan secara baik dan benar".

Analisis rasio keuangan adalah suatu metode analisis untuk mengetahui hubungan dari pos-pos tertentu dalam neraca atau laporan laba rugi secara individu atau kombinasi dari kedua laporan tersebut.mAnalisis rasio keuangan menurut Munawir (2010:106), adalah:mFutured Oriented atau berorientasi dengan masa depan, artinya bahwa dengan analisa ratio keuangan dapat digunakan sebagai alat untuk meramalkan keadaan keuangan serta hasil usaha dimasa yang akan datang. 
Dengan angka-angka ratio historis atau kalau memungkinkan dengan angka rasio industri (yang dilengkapi dengan data lainnya) dapat digunakan sebagai dasar untuk penyusunan laporan keuangan yang diproyeksikan yang merupakan salah satu bentuk perencanaan keuangan perusahaan.

Analisis rasio metode radar dikembangkan oleh APO (Asian Productifity Organization) yang berpusat di Tokyo, Jepang. Analisis radar merupakan rasio penyempurnaan dari analisis rasio keuangan lainnya, yang bertujuan dalam memberikan gambaran menyeluruh serta mengetahui perkembangannya. (Setyawan et al., 2006), menyatakan bahwa analisis rasio radar dikelompokkan dalam lima kelompok besar yaitu sebagai berikut : Rasio profitabilitas merupakan rasio yang mengukur kinerja manajemen secara keseluruhan yang ditunjukkan oleh besar kecilnya tingkat keuntungan yang diperoleh dalam hubungannya dengan tingkat penjualan dan investasi.

\begin{tabular}{|c|c|c|}
\hline \multirow[t]{2}{*}{ Return On Investment } & \multirow[t]{2}{*}{$=$} & Laba bersih \\
\hline & & Total aktiva \\
\hline \multirow[t]{2}{*}{ Gross Profit Margin } & \multirow[t]{2}{*}{$=$} & Penjualan-Beban Pokok Penjualan \\
\hline & & Penjualan \\
\hline \multirow[t]{2}{*}{ Net Profit Margin } & \multirow[t]{2}{*}{$=$} & Laba bersih \\
\hline & & Penjualan \\
\hline \multirow[t]{2}{*}{ Return On Network } & \multirow[t]{2}{*}{$=$} & Laba penjualan \\
\hline & & Penjualan \\
\hline Sales to Sales administration & $=$ & Penjualan \\
\hline And Selling Expense & & Beban - Beban penjualan \\
\hline
\end{tabular}


Rasio produktivitas merupakan rasio spesifik analisis radar, yang mencerminkan indikator produktivitas faktor produksi manusia didalam perusahaan.

Sales per employee

Net added value per employee

Equipment to labour

Wages distribution ratio

$$
=\frac{\text { Penjualan }}{\text { Jumlah Karyawan }}
$$

= Biaya karyawan + Laba Operasi

Jumlah jenjang gaji

$=$ Nilai bersih perusahaan

Jumlah tenaga kerja

$=$ Nilai bersih perusahaan

Jumlah tenaga kerja

Wages base trend / incentive base
$=$ Nilai bersih perusahaan

Jumlah tenaga kerja

Rasio utilitas aktiva merupakan rasio gabungan dari rasio pengelolaan aktiva yang mengukur seberapa efektif perusahaan mengelola aktivanya.

$\begin{array}{lll}\text { Total assets turnover } & = & \frac{\text { Penjualan }}{\text { Total Aktiva }} \\ \text { Working capital turnover } & =\frac{\text { Penjualan }}{\text { Aktiva lancar }} \\ \text { Account receivable } & = & \frac{\text { Penjualan }}{\text { Piutang Bersih }}\end{array}$




$$
\begin{array}{ll}
\text { Investory turnover } & =\quad \frac{\text { Penjualan/Beban pokok penjualan }}{\text { Persediaan }} \\
\text { Fixed assets turnover } & =\frac{\text { Penjualan }}{\text { Total aktiva tetap }}
\end{array}
$$

Rasio stabilitas merupakan gabungan rasio likuiditas dan rasio solvabilitas pada analisa klasik, karena rasio tersebut pada hakekatnya adalah indikator stabilitas jangka pendek dan jangka panjang perusahaan.

Net fixed tangible assets to long-tern debt and networth

$\begin{array}{ll} & =\frac{\text { Aktiva tetap bersih }}{\text { Pinjaman jangka panjang+ Moda }} \\ \text { Debt to equity } & =\frac{\text { Pinjaman jangka panjang }}{\text { Modal Sendiri }} \\ & =\frac{\text { Aktiva lancar }- \text { Persediaan }}{\text { Utang lancar }} \\ \text { Cuick ratio } & =\frac{\text { Aktiva lancar }}{\text { Utang lancar } 100 \%} \\ \text { Interest charges ratio } & =\quad \frac{\text { Beban bunga }}{\text { Penjualan }}\end{array}$

Analisis rasio yang telah mencakup rasio pertumbuhan, tetapi belum memasukkan kekuatan bersaing. Rasio ini digunakan untuk mengetahui rata-rata pertumbuhan perusahaan.

Sales growth

$$
=\frac{\text { Penjualan }}{\text { Penjualan }-1}
$$




$\begin{array}{lll}\text { Net added value to sales growth } & = & \frac{\text { Nilai tambah bersih }-1}{\text { Pertumbuhan penjualan }} \\ \text { Labour strength increase } & = & \frac{\text { Biaya tenaga kerja }-1}{\text { Jumlah tenaga kerja }-1} \\ \text { Networt increase ratio } & = & \frac{\text { Modal sendiri }}{\text { Modal sendiri }-1} \\ \text { Net profit increase ratio } & = & \frac{\text { Laba bersih }}{\text { Laba bersih }-1}\end{array}$

Arfamaini (2017) meneliti mengenai "Perbandingan analisa kinerja keuangan perusahaan ban yang terdaftar di bursa efek Indonesia (BEI) tahun 2013 dengan menggunakan rasio-rasio dalam metode radar". Hasil penelitian ini menunjukan dari perhitungan metode radar PT Goodyer Indonesia Tbk yang paling bagus diantara beberapa perusahaan yang sejenis.

Ansari (2018), meneliti mengenai "Penggunaan metode dupont dan radar dalam hubungan dengan pengukuran kinerja keuangan setelah akuisisi”. Dari hasil penelitian disebutkan penelitian kinerja perusahaan baik dengan metode dupont dan metode radar memperlihatkan hasil yang sangat memperkuat.

\section{METODE PENELITIAN}

Penelitian yang digunakan adalah jenis penelitian deskriptif. Sebagaimana dikemukakan oleh Sugiyono (2014:21) bahwa : Metode analisis deskriptif adalah statistik yang digunakan untuk menganalisis data dengan cara mendeskripsikan atau menggambarkan data yang telah terkumpul sebagaimana adanya tanpa bermaksud membuat kesimpulan yang berlaku untuk umum atau generalisasi. Data yang 
digunakan adalah data kuantitatif laporan keuangaan perusahaan semen pada tahun 2015-2017. Dan sumber data laporan keuangan yang diambil dari Bursa Efek Indonesia (BEI).

\section{HASIL DAN PEMBAHASAN}

Tabel 1.

Rasio Profitabilitas 2015

\begin{tabular}{cccc}
\hline Rasio Profitabilitas & $\begin{array}{c}\text { PT } \\
\text { Indocement } \\
\text { tunggal } \\
\text { Prakarsa } \\
\text { Tbk }\end{array}$ & $\begin{array}{c}\text { PT Semen } \\
\text { Baturaja } \\
\text { (Persero) Tbk }\end{array}$ & $\begin{array}{c}\text { PT Holcim } \\
\text { Indonesia Tbk }\end{array}$ \\
\hline Return On Investment & 0.157 & 108.37 & 10.11 \\
Gross Profit Margin & 0.444 & $(-661)$ & 0.231 \\
Net Profit Margin & 0.317 & 303.5 & 37.92 \\
Return On Network & 0.317 & 303.5 & 37.92 \\
Sales to Sales & & & 26 \\
administration And Selling & 25 & 9.48 & \\
Expense & & & \\
\hline
\end{tabular}

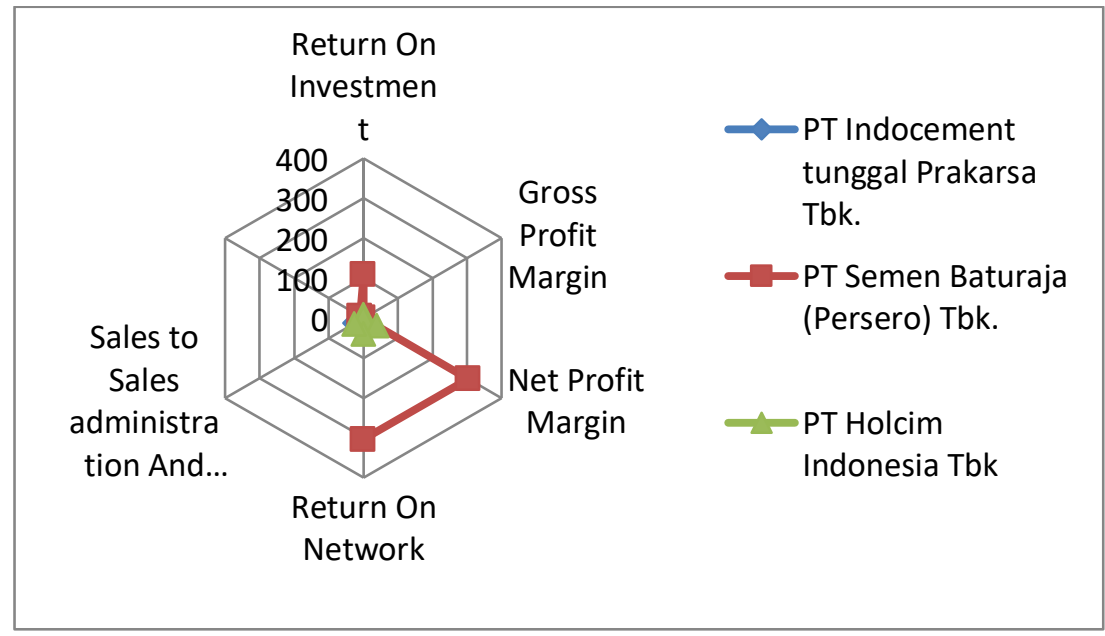

Gambar 1.

Grafik Rasio Profitabilitas 2015 
Tabel 2.

Rasio Profitabilitas 2016

\begin{tabular}{cccc}
\hline $\begin{array}{c}\text { Rasio Profitabilitas } \\
\mathbf{2 0 1 6}\end{array}$ & $\begin{array}{c}\text { PT } \\
\text { Indocement } \\
\text { tunggal } \\
\text { Prakarsa } \\
\text { Tbk }\end{array}$ & $\begin{array}{c}\text { PT Semen } \\
\text { Baturaja } \\
\text { (Persero) Tbk }\end{array}$ & $\begin{array}{c}\text { PT Holcim } \\
\text { Indonesia Tbk }\end{array}$ \\
\hline Return On Investment & 0.128 & 59.30 & 38.62 \\
Gross Profit Margin & 0.412 & 0.335 & 0.204 \\
Net Profit Margin & 0.269 & 229.4 & 22.62 \\
Return On Network & 0.269 & 229.4 & 22.62 \\
Sales to Sales & 2.3 & 9.69 & 152 \\
administration And & & & \\
Selling Expense & & & \\
\hline
\end{tabular}

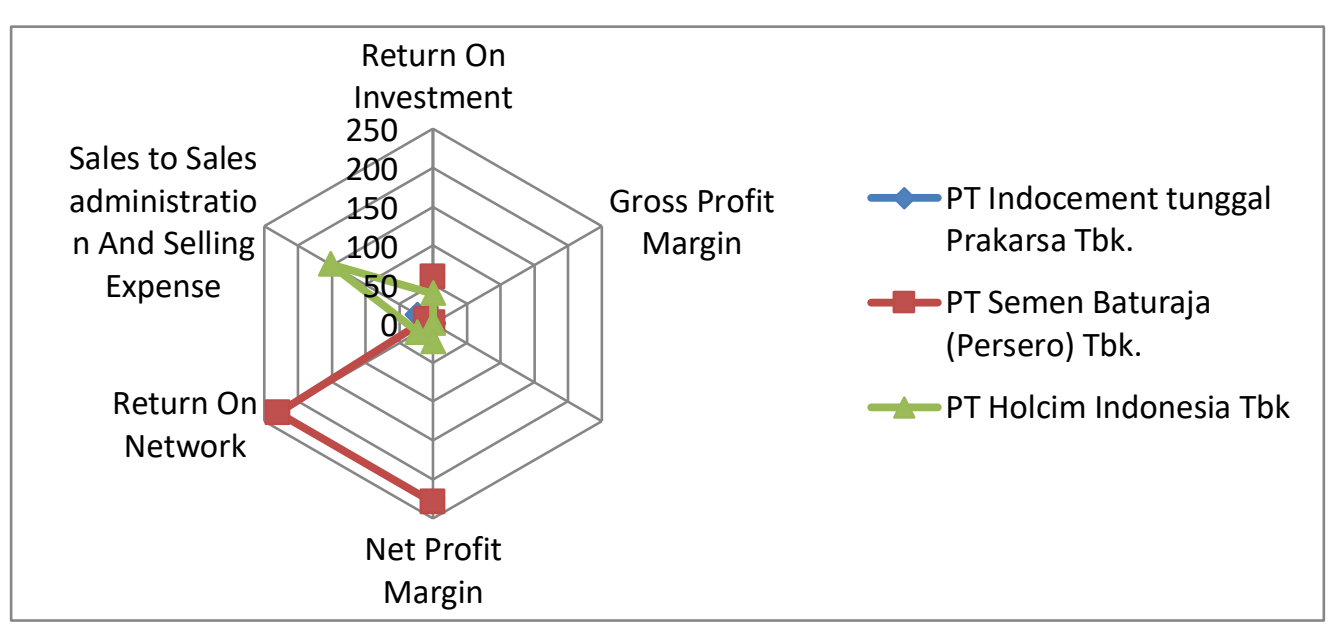

Gambar 2.

Grafik Profitabilitas 2016

Tabel 3.

Rasio Profitabilitas 2017

\begin{tabular}{cccc}
\hline $\begin{array}{c}\text { Rasio Profitabilitas } \\
\mathbf{2 0 1 7}\end{array}$ & $\begin{array}{c}\text { PT Indocement } \\
\text { tunggal Prakarsa } \\
\text { Tbk }\end{array}$ & $\begin{array}{c}\text { PT Semen } \\
\text { Baturaja } \\
\text { (Persero) Tbk }\end{array}$ & $\begin{array}{c}\text { PT Holcim } \\
\text { Indonesia Tbk }\end{array}$ \\
\hline Return On Investment & 0.064 & 28.98 & 14.39 \\
\hline
\end{tabular}


Lanjutan

Tabel 3.

Rasio Profitabilitas 2017

\begin{tabular}{|c|c|c|c|}
\hline $\begin{array}{c}\text { Rasio Profitabilitas } \\
2017\end{array}$ & $\begin{array}{c}\text { PT Indocement } \\
\text { tunggal } \\
\text { Prakarsa Tbk }\end{array}$ & $\begin{array}{c}\text { PT Semen } \\
\text { Baturaja } \\
\text { (Persero) Tbk }\end{array}$ & $\begin{array}{c}\text { PT Holcim } \\
\text { Indonesia Tbk }\end{array}$ \\
\hline
\end{tabular}

$\begin{array}{cccc}\text { Gross Profit Margin } & 0.347 & 0.304 & 0.199 \\ \text { Net Profit Margin } & 0.158 & 134.7 & 23.64 \\ \text { Return On Network } & 0.158 & 134.7 & 23.64 \\ \quad \text { Sales to Sales } & 1.9 & 9.12 & 77 \\ \begin{array}{c}\text { administration And } \\ \text { Selling Expense }\end{array} & & & \end{array}$

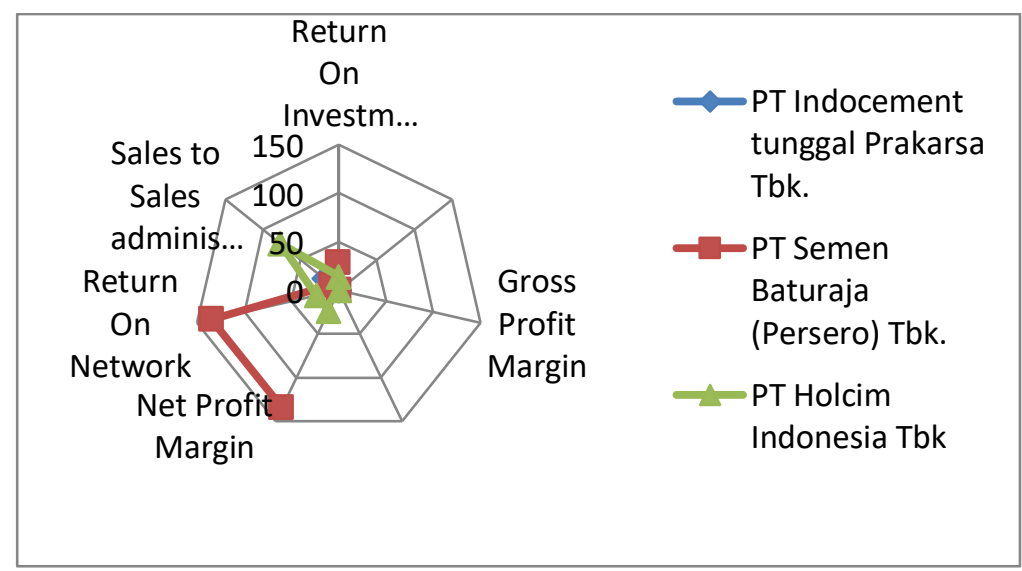

Gambar 3.

Grafik Rasio Profitabilitas 2017

Analisa Rasio Profitabilitas. PT Semen Baturaja (Persero) Tbk memiliki tingkat Return on Investment paling tinggi pada tahun 2015, 2016 dan 2017 yaitu 108.37, 59.30 dan 28.98. Sedangkan paling rendah pada tahun 2015, 2016 dan 2017 PT Indocement Tunggal Prakarsa yaitu 0.157, 0.128 dan 0.064 . PT Semen Baturaja (Persero) Tbk memiliki Gross Profit Margin paling tinggi ditahun 2015 yaitu -661. Sedangkan pada tahun 2016 dan 2017 paling tinggi PT Indocement Tunggal 
Prakarsa Tbk yaitu 0.412 dan 0.347. Sedangkan Gross Profit Margin paling rendah pada tahun 2015, 2016 dan 2017 PT Holcim Indonesia Tbk yaitu 0.231, 0.204, dan 0.199. PT Indocement Tunggal Prakarsa Tbk memiliki Net Profit Margin paling tinggi pada tahun 2015,2016, dan 2017 yaitu 0.317, 0.269, dan 0.158. Sedangkan PT Semen Baturaja (Persero) Tbk memiliki Return on Network dan Net Profit Margin, paling tinggi pada tahun 2015,2016, dan 2017 yaitu 303.5, 299.4,dan 134.7. PT Semen Baturaja (Persero) Tbk memiliki Return on Network paling tinggi pada tahun 2015,2016, dan 2017 yaitu 303.5, 299.4,dan 134.7 Sedangkan pada tahun 2015, 2016 dan 2017 paling rendah PT Indocement Tunggal Prakarsa Tbk yaitu $0.317,0.269$, dan 0.158. PT Holcim Indonesia Tbk memiliki Sales to Sales Administration and Selling Expenses paling tinggi pada tahun 2015,2016 dan 2017 yaitu 26\%, 152\% dan 77\%. .Sedangkan rendah pada tahun 2015,2016 dan 2017 adalah PT Semen Baturaja (Persero) Tbk yaitu 9.48\%, $9.69 \%$ dan 9.12\%.

Tabel 4.

Rasio Produktivitas 2015

\begin{tabular}{cccc}
\hline $\begin{array}{c}\text { Rasio Produktivitas } \\
\mathbf{2 0 1 5}\end{array}$ & $\begin{array}{c}\text { PT } \\
\text { Indocement } \\
\text { tunggal } \\
\text { Prakarsa Tbk }\end{array}$ & $\begin{array}{c}\text { PT Semen } \\
\text { Baturaja } \\
\text { (Persero) Tbk }\end{array}$ & $\begin{array}{c}\text { PT Holcim Indonesia } \\
\text { Tbk }\end{array}$ \\
\hline $\begin{array}{c}\text { Sales per employee } \\
\text { Net added value per } \\
\text { employee }\end{array}$ & 2.56 & 2.45 & 3.62 \\
$\begin{array}{c}\text { Equipment to labour } \\
\text { Wages distribution } \\
\text { ratio }\end{array}$ & 0.626 & 11 & 0.872 \\
Wages base trend & 0.626 & 0.595 & 68 \\
& 0.626 & 0.595 & 68 \\
\hline
\end{tabular}




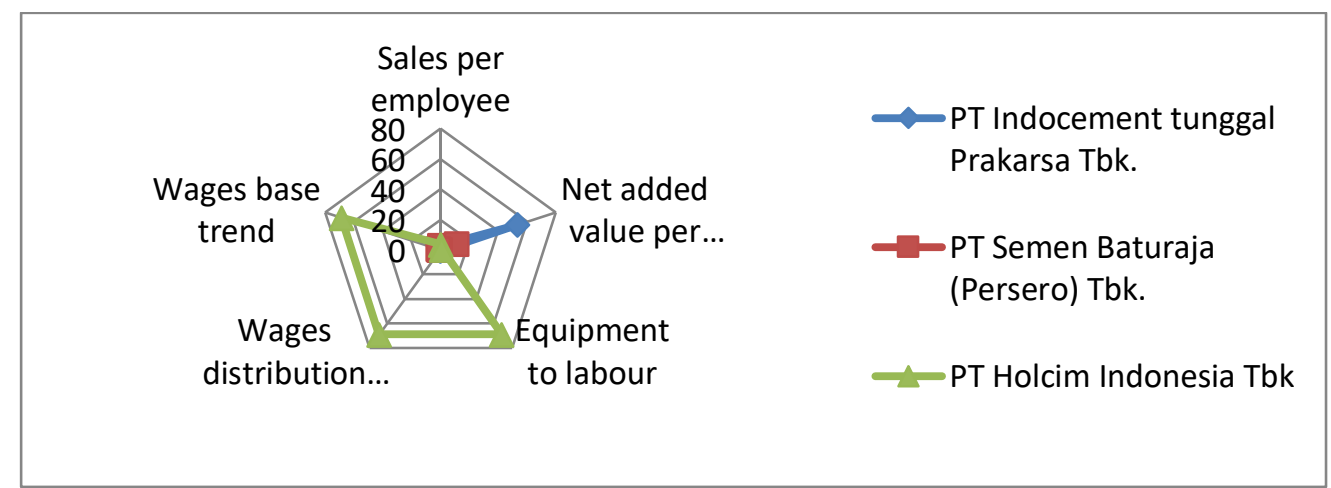

Gambar 4.

Grafik Rasio Produktivitas 2015

Tabel 5.

Rasio Produktivitas 2016

\begin{tabular}{cccc}
\hline $\begin{array}{c}\text { Rasio Produktivitas } \\
\mathbf{2 0 1 6}\end{array}$ & $\begin{array}{c}\text { PT } \\
\text { Indocement } \\
\text { tunggal } \\
\text { Prakarsa } \\
\text { Tbk }\end{array}$ & $\begin{array}{c}\text { PT Semen } \\
\text { Baturaja } \\
\text { (Persero) Tbk }\end{array}$ & $\begin{array}{c}\text { PT Holcim Indonesia } \\
\text { Tbk }\end{array}$ \\
\hline $\begin{array}{c}\text { Sales per employee } \\
\text { Net added value per } \\
\text { employee }\end{array}$ & 2.33 & 2.65 & 3.58 \\
$\begin{array}{c}\text { Equipment to labour } \\
\text { Wages distribution } \\
\text { ratio }\end{array}$ & 0.37 & 36.55 & 0.321 \\
Wages base trend & 0.588 & 0.451 & 107 \\
& 0.588 & 0.451 & 107 \\
\hline
\end{tabular}

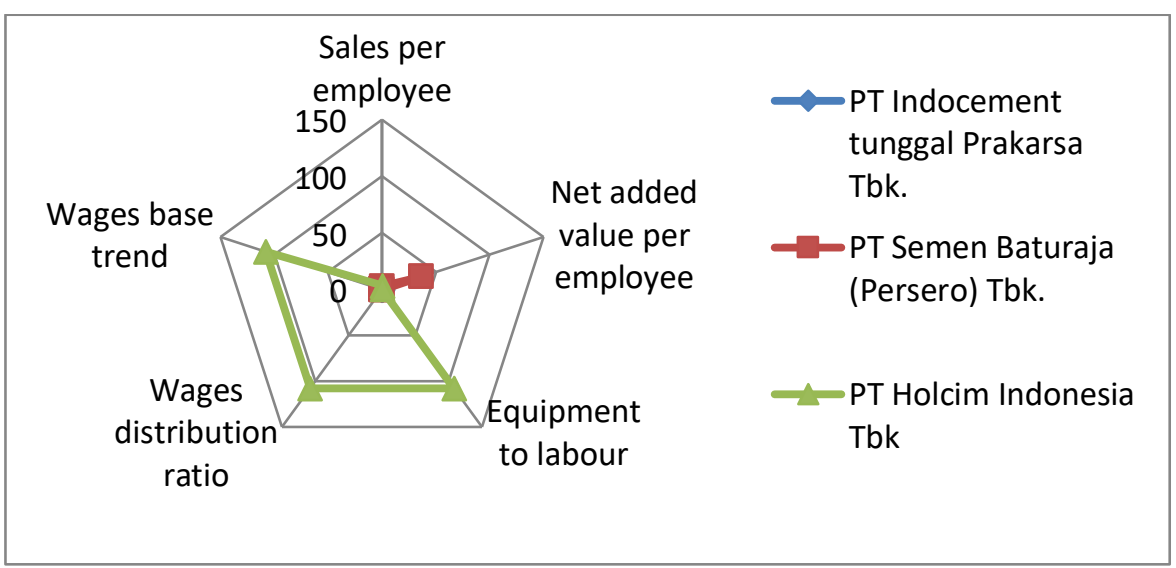


Gambar 5.

Grafik Rasio Produktivitas 2016

Tabel 6.

Rasio Produktivitas 2017

\begin{tabular}{cccc}
\hline $\begin{array}{c}\text { Rasio Produktivitas } \\
\mathbf{2 0 1 7}\end{array}$ & $\begin{array}{c}\text { PT } \\
\text { Indocement } \\
\text { tunggal } \\
\text { Prakarsa } \\
\text { Tbk. }\end{array}$ & $\begin{array}{c}\text { PT Semen } \\
\text { Baturaja } \\
\text { (Persero) Tbk. }\end{array}$ & $\begin{array}{c}\text { PT Holcim Indonesia } \\
\text { Tbk }\end{array}$ \\
\hline $\begin{array}{c}\text { Sales per employee } \\
\text { Net added value per } \\
\text { employee }\end{array}$ & 0.498 & 2 & 3.70 \\
$\begin{array}{c}\text { Equipment to labour } \\
\text { Wages distribution } \\
\text { ratio }\end{array}$ & 0.304 & 17 & 299 \\
Wages base trend & 0.304 & 0.189 & 299 \\
\hline
\end{tabular}

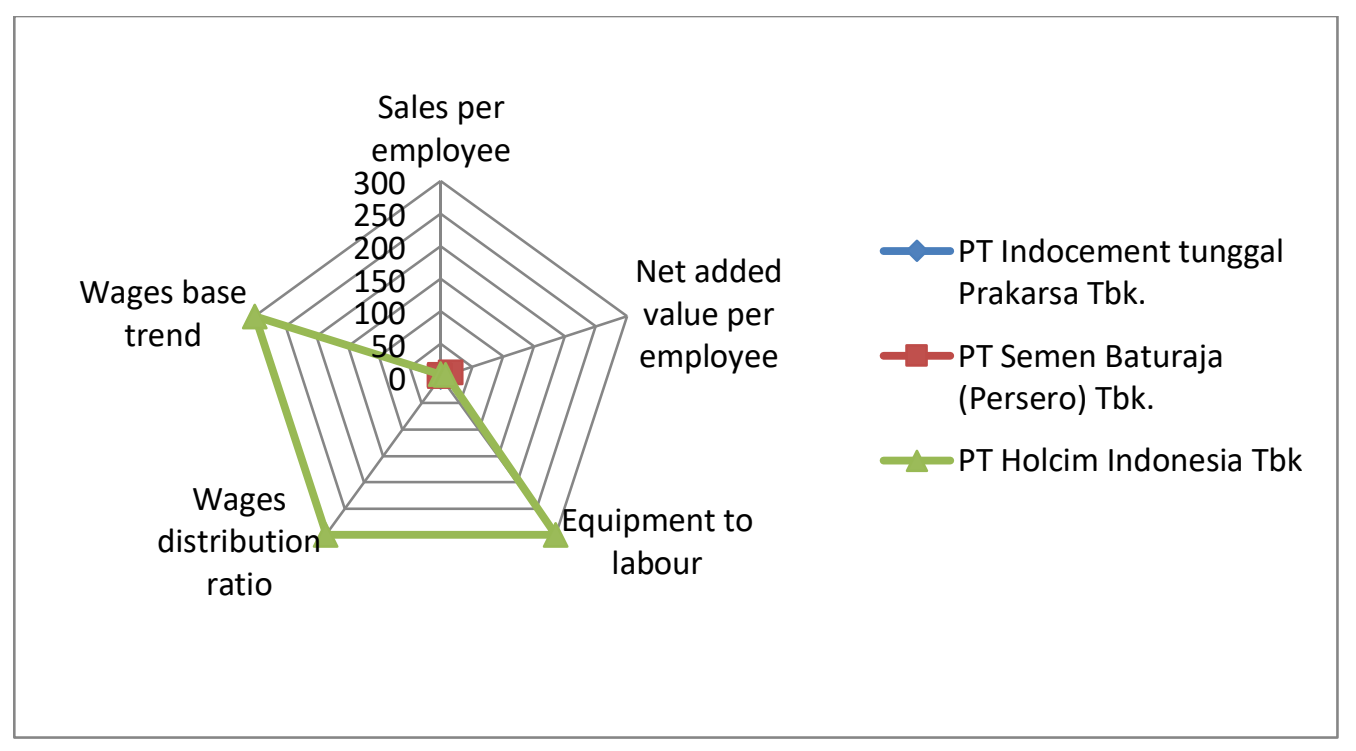

Gambar 6.

Grafik Rasio Produktivitas 2017

Analisa Rasio Produktivitas. PT Holcim Indonesia Tbk memiliki Sales per Employee paling tinggi pada tahun 2015,2016,2017 yaitu 3.62, 3.58, 3.70 dan PT 
Semen Baturaja (Persero) Tbk memiliki paling kecil pada tahun 2015 dan 2017 yaitu 2.45 dan 2. Pada Tahun 2016 paling rendah PT Indocement Tunggal prakarsa Tbk yaitu 2.33. PT Indocement Tunggal Prakarsa Tbk memiliki Net added value per employee paling tinggi pada tahun 2015 yaitu 53 dan PT Semen Baturaja (Persero) Tbk pada tahun 2016 dan 2017 yaitu 36.55 dan 17. Sedangkan yang paling rendah pada tahun 2015 PT Holcim Indonesia Tbk yaitu 0.872 pada tahun 2016 dan 2017 PT Indocement Tunggal Prakarsa Tbk yaitu 0.37 dan 0.498. PT Holcim Indonesia Tbk pada tahun 2015, 2016 dan 2017 memiliki Equipment To Labour, Wages Distribution Ratio, dan Wages Base Trend paling tinggi yaitu 68, 107 dan 299. Sedangkan PT Semen Baturaja (Persero) Tbk paling rendah yaitu 0.595, 0.451, dan 0.189 .

Tabel 7.

Rasio Utilitas Aktiva 2015

\begin{tabular}{cccc}
\hline $\begin{array}{c}\text { Rasio Utilitas Aktiva } \\
\mathbf{2 0 1 5}\end{array}$ & $\begin{array}{c}\text { PT } \\
\text { Indocement } \\
\text { tunggal } \\
\text { Prakarsa Tbk }\end{array}$ & $\begin{array}{c}\text { PT Semen } \\
\text { Baturaja } \\
\text { (Persero) Tbk }\end{array}$ & $\begin{array}{c}\text { PT Holcim Indonesia } \\
\text { Tbk }\end{array}$ \\
\hline $\begin{array}{c}\text { Total Assets Turnover } \\
\text { Working Capital } \\
\text { Turnover }\end{array}$ & 0.643 & 0.444 & 0.533 \\
Account Receivable & 1.35 & 0.748 & 3.57 \\
Investory Turnover & 7.09 & 0.008 & 8.74 \\
& 11.7 & 0.01 & 0.016 \\
Fixed assets turnover & 1.28 & & 0.64 \\
\hline
\end{tabular}




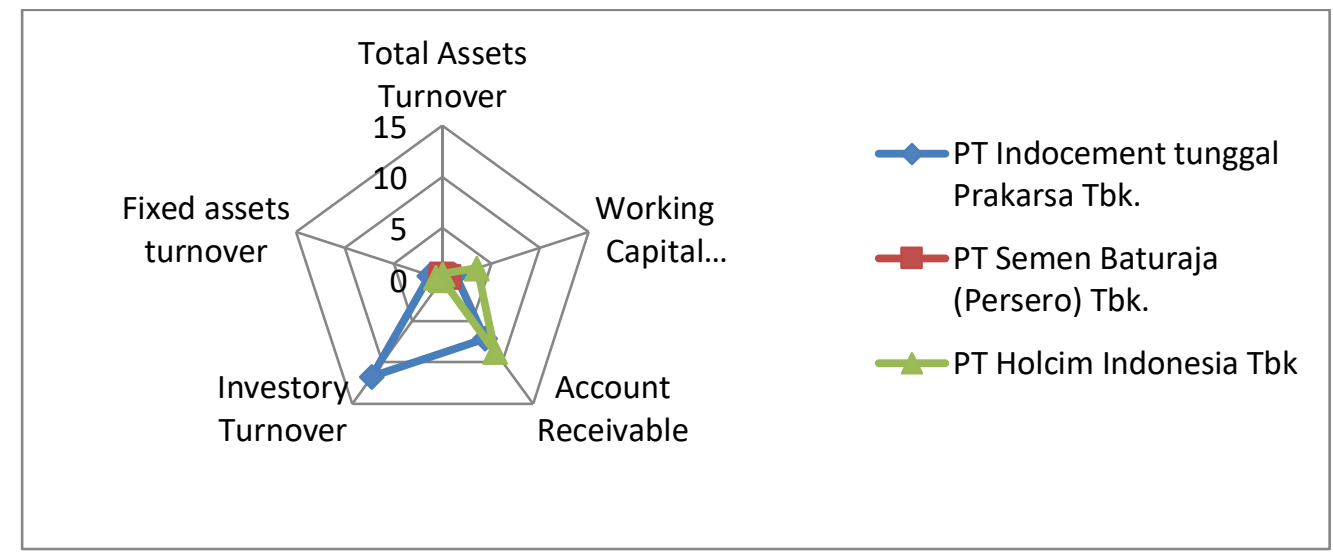

Gambar 7.

Grafik Rasio Utilitas Aktiva 2015

Tabel 8.

Rasio Utilitas Aktiva 2016

\begin{tabular}{cccc}
\hline $\begin{array}{c}\text { Rasio Utilitas Aktiva } \\
\mathbf{2 0 1 6}\end{array}$ & $\begin{array}{c}\text { PT } \\
\text { Indocement } \\
\text { tunggal } \\
\text { Prakarsa } \\
\text { Tbk }\end{array}$ & $\begin{array}{c}\text { PT Semen } \\
\text { Baturaja } \\
\text { (Persero) Tbk }\end{array}$ & $\begin{array}{c}\text { PT Holcim Indonesia } \\
\text { Tbk }\end{array}$ \\
\hline $\begin{array}{c}\text { Total Assets Turnover } \\
\text { Working Capital } \\
\text { Turnover }\end{array}$ & 0.509 & 0.348 & 0.478 \\
Account Receivable & 1.06 & 0.001 & 3.83 \\
Investory Turnover & 6.05 & 1.40 & 9.24 \\
Fixed assets turnover & 8.62 & 0.008 & 0.012 \\
\hline
\end{tabular}

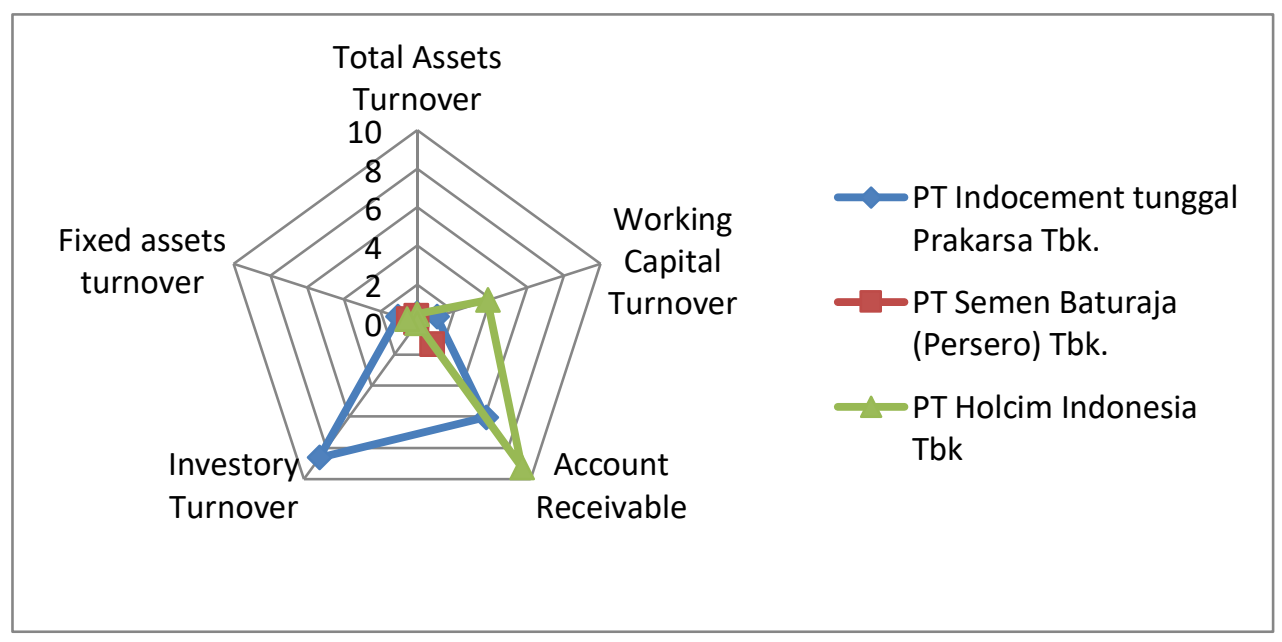




\section{Gambar 8.}

Grafik Rasio Utilitas Aktiva 2016

Tabel 9.

Utilitas Aktiva 2017

\begin{tabular}{cccc}
\hline $\begin{array}{c}\text { Rasio Utilitas Aktiva } \\
\mathbf{2 0 1 7}\end{array}$ & $\begin{array}{c}\text { PT } \\
\text { Indocement } \\
\text { tunggal } \\
\text { Prakarsa Tbk }\end{array}$ & $\begin{array}{c}\text { PT Semen } \\
\text { Baturaja } \\
\text { (Persero) Tbk }\end{array}$ & $\begin{array}{c}\text { PT Holcim Indonesia } \\
\text { Tbk }\end{array}$ \\
\hline $\begin{array}{c}\text { Total Assets Turnover } \\
\text { Working Capital } \\
\text { Turnover }\end{array}$ & 0.499 & 0.306 & 0.478 \\
$\begin{array}{c}\text { Account Receivable } \\
\text { Investory Turnover }\end{array}$ & 1.12 & 1.38 & 3.20 \\
Fixed assets turnover & 8.16 & 0.13 & 7.99 \\
\end{tabular}

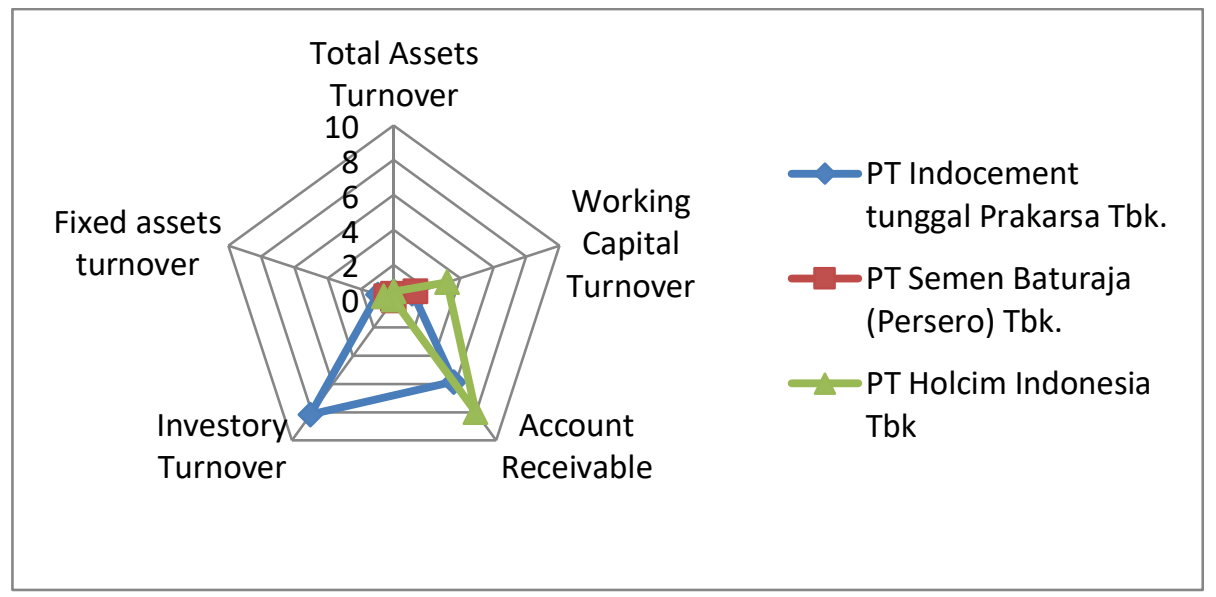

Gambar 9.

Grafik Rasio Utilitas Aktiva 2017

Analisa Rasio Utilitas Aktiva. PT. Indocement Tunggal Prakarsa Tbk memiliki Total Assets Turnover lebih besar pada tahun 2015, 2016 dan 2017 yaitu berputar 0.643, 0.509 dan 0.499 kali. Sedangkan PT Semen Baturaja (Persero) Tbk pada tahun 2015, 2016 dan 2017 memiliki perputaran aset lebih kecil yaitu 0.444, 
0.348 dan 0.306 kali. PT Holcim Indonesia Tbk memiliki Working Capital Turnover paling besar pada tahun 2015.2016 dan 2017 yaitu 3.57, 3.83 dan 3.20 kali. Sedangkan PT Semen Baturaja (Persero) Tbk pada tahun 2015 dan 2016 memiliki Working Capital Turnover paling kecil yaitu 0.748 kali dan 0.001.Dan Pada tahun 2017 PT. Indocemen Tunggal Prakarsa Tbk yaitu 1.12 kali. PT Semen Baturaja (Persero) Tbk memiliki Account Receivable Turnover paling bagus pada tahun 2015,2016 dan 2017 yaitu 0.008, 1.40, dan 0.13 kali. Sedangkan PT Holcim Indonesia Tbk pada tahun 2015,2016,2017 memiliki Account Receivable Turnover kemampuan dalam menagih piutangnya lebih lama yaitu membutuhkan 8.74, 9.24 dan 7.99 kali. Perputaran persediaan paling besar pada PT Indocement Tunggal Prakarsa, Tbk pada tahun 2015, 2016 dan 2017 yaitu 11.7, 8.62, 8.16. Sedangkan yang paling sedikit adalah PT.Semen Baturaja (Persero) Tbk pada tahun 2015,2016,2017 yaitu 0.01,0.008 dan 0.007 kali. Perputaran Aktiva Tetap terhadap penjualan paling besar adalah PT Indocement Tunggal Prakarsa Tbk pada tahun 2015,2016,2017 yaitu 1.28, 1.04, 0.963 kali. Sedangkan perputaran Aktiva Tetap paling sedikit adalah PT Semen Baturaja (Persero) Tbk Pada tahun 2015,2016,2017 yaitu 0,0.437.0.403 kali.

Tabel 10.

Rasio Stabilitas 2015

\begin{tabular}{cccc}
\hline Rasio Stabilitas & $\begin{array}{c}\text { PT Indocement } \\
\text { tunggal Prakarsa } \\
\text { Tbk }\end{array}$ & $\begin{array}{c}\text { PT Semen } \\
\text { Baturaja } \\
\text { (Persero) Tbk }\end{array}$ & $\begin{array}{c}\text { PT Holcim Indonesia } \\
\text { Tbk }\end{array}$ \\
\hline $\begin{array}{c}\text { Net fixed tangible Assets } \\
\text { to long-tern debt and } \\
\text { networth }\end{array}$ & 0.578 & 266 & 1.04 \\
Debt to Equity & 2.3 & 2.9 & 0.630 \\
\hline
\end{tabular}


Tabel 10.

Rasio Stabilitas 2015

\begin{tabular}{cccc}
\hline Rasio Stabilitas & $\begin{array}{c}\text { PT Indocement } \\
\text { tunggal } \\
\text { Prakarsa Tbk }\end{array}$ & $\begin{array}{c}\text { PT Semen } \\
\text { Baturaja } \\
\text { (Persero) } \\
\text { Tbk }\end{array}$ & $\begin{array}{c}\text { PT Holcim Indonesia } \\
\text { Tbk }\end{array}$ \\
\hline Quick Ratio & 4.3 & -071 & -139 \\
Current Ratio & 4.8 & 757 & 0.652 \\
Interest charges ratio & 38.9 & 130.3 & 61
\end{tabular}

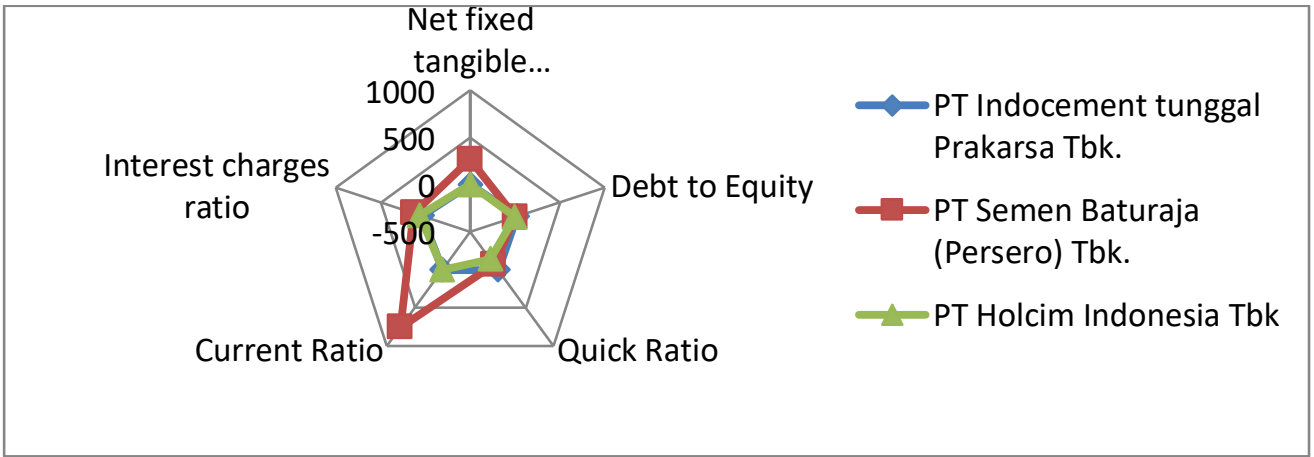

Gambar 10.

Grafik Rasio Stabilitas 2015

Tabel 11.

Rasio Stabilitas 2016

\begin{tabular}{cccc}
\hline Rasio Stabilitas & $\begin{array}{c}\text { PT Indocement } \\
\text { tunggal } \\
\text { Prakarsa Tbk }\end{array}$ & $\begin{array}{c}\text { PT Semen } \\
\text { Baturaja } \\
\text { (Persero) Tbk }\end{array}$ & $\begin{array}{c}\text { PT Holcim } \\
\text { Indonesia } \\
\text { Tbk }\end{array}$ \\
\hline $\begin{array}{c}\text { Net fixed tangible Assets to } \\
\text { long-tern debt and networth }\end{array}$ & 0.560 & 496 & 1.40 \\
Debt to Equity & 26 & 179 & 0.470 \\
Quick Ratio & 3.9 & 2.2 & -143 \\
Current Ratio & 4.5 & 2.8 & 0.464 \\
Interest charges ratio & 43 & 4.6 & 40 \\
\hline
\end{tabular}




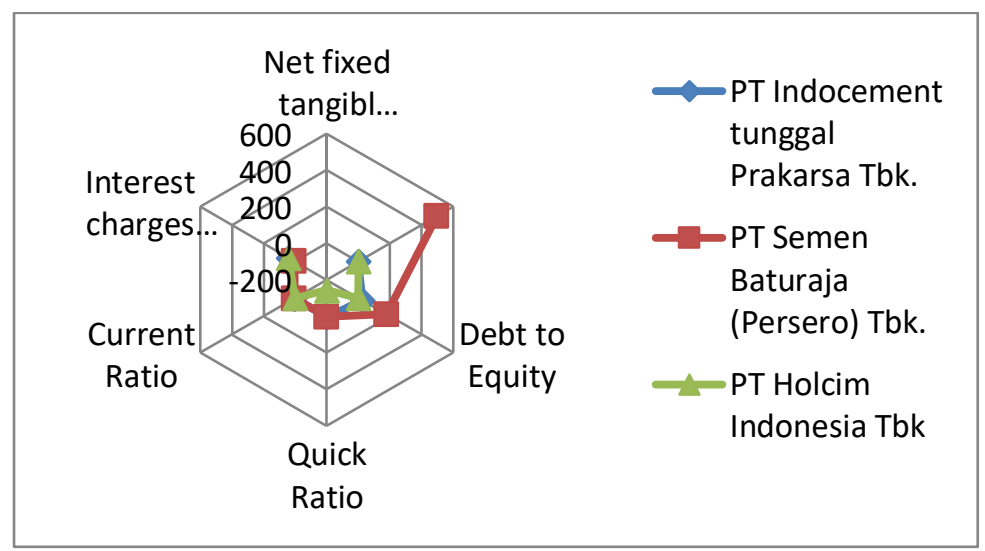

Gambar 11.

Grafik Rasio Stabilitas 2016

Tabel 12.

Rasio Stabilitas 2017

\begin{tabular}{cccc}
\hline Rasio Stabilitas & $\begin{array}{c}\text { PT Indocement } \\
\text { tunggal } \\
\text { Prakarsa Tbk }\end{array}$ & $\begin{array}{c}\text { PT Semen } \\
\text { Baturaja } \\
\text { (Persero) Tbk }\end{array}$ & $\begin{array}{c}\text { PT Holcim } \\
\text { Indonesia Tbk }\end{array}$ \\
$\begin{array}{c}\text { Net fixed tangible Assets to } \\
\text { long-tern debt and networth }\end{array}$ & 0.609 & 361 & 1.41 \\
Debt to Equity & 24 & 244 & 0.576 \\
Quick Ratio & 3.19 & -0.302 & -163 \\
Current Ratio & 3.70 & 167 & 0.543 \\
Interest charges ratio & 51.4 & 480.7 & 97.2 \\
\hline
\end{tabular}

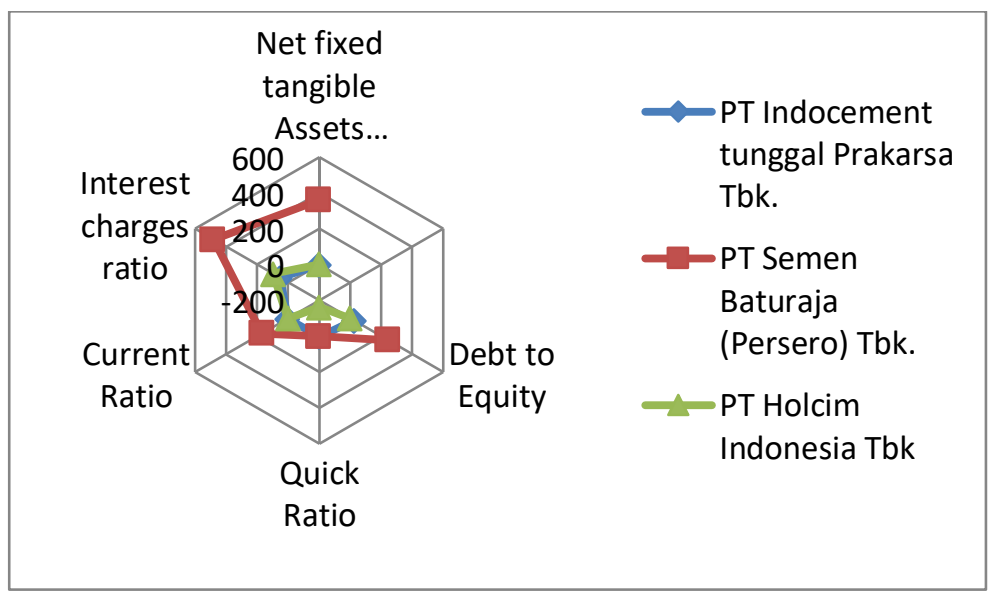




\section{Gambar 12.}

\section{Grafik Rasio Stabilitas 2017}

Analisa Rasio Stabilitas. PT Holcim Indonesia Tbk memiliki Next Fixed Tangible Assets to Longterm Debt and Networth paling besar pada tahun 2015,2016,2017 yaitu 1.04,1.40,1.41 dan yang paling kecil adalah Indocement Tunggal Prakarsa Tbk pada tahun 2015,2016,2017 yaitu 0.578, 0.560, dan 0.609. PT Semen Baturaja (Persero) Tbk pada tahun 2016 dan 2017 sebesar 179\% dan 244\% tidak memiliki kemampuan dalam melunasi hutang jangka panjangnya terhadap modal sendiri (Debt to Equity). PT Semen Baturaja (Persero) Tbk pada tahun 2015 dan 2017 tidak mampu melunasi hutang lancarnya dengan menggunakan aktiva lancar tanpa persediaan (Quick Ratio) karena presentase aktiva lancar tanpa persediaan terhadap hutang lancar hanya -0,71 dan -0302. Pada tahun 2016 PT Holcim Indonesia Tbk sebesar -143. Hanya PT Indocement Tunggal Prakarsa Tbk yang lebih tinggi dalam melunasi hutang lancarnya pada tahun 2015,2016 dan 2017 yaitu 4.3, 3.96 dan 3.19. PT Holcim IndonesiaTbk pada tahun 2015,2016 dan 2017 tidak mampu melunasi hutang lancar dengan menggunakan aktiva lancar. Yaitu 0.652, 0.464 dan 0.543. Sedangkan yang lainnya PT Indocement Tunggal Prakarsa Tbk, dan PT Semen Baturaja (Persero) Tbk dapat melunasi hutang lancarnya. PT Indocement Tunggal Prakarsa Tbk memiliki Interest Charge Ratio paling tinggi pada tahun 2015,2016 yaitu 38.9, 43 dan PT Semen Baturaja (Persero)Tbk pada tahun 2017 yaitu 480.7. Sedangkan yang paling rendah pada tahun 2015 PT Holcim Indonesia Tbk yaitu 61. Pada tahun 2016 PT Semen Baturaja (Persero) Tbk yaitu 4.6. Dan pada tahun 2017 paling rendah PT Indocement Tunggal Prakarsa Tbk memiliki Interest Charge Ratio paling rendah sebesar 51.4. 
Tabel 13.

Rasio Potensi Pertumbuhan 2015

\begin{tabular}{cccc}
\hline Rasio Potensi Pertumbuhan & $\begin{array}{c}\text { PT } \\
\text { Indocement } \\
\text { tunggal } \\
\text { Prakarsa } \\
\text { Tbk. }\end{array}$ & $\begin{array}{c}\text { PT Semen } \\
\text { Baturaja } \\
\text { (Persero) Tbk. }\end{array}$ & $\begin{array}{c}\text { PT Holcim } \\
\text { Indonesia Tbk }\end{array}$ \\
\hline Sales Growth & 0.89 & 1.20 & 0.974 \\
Net added value to sales & 104 & 485 & 57 \\
growth & 64 & 13 & 0.565 \\
Labour strength increase & 0.971 & 1.10 & 0.985 \\
Network increase ratio & 0.823 & 1.05 & 0.265 \\
Net profit increase ratio & & & \\
\hline
\end{tabular}

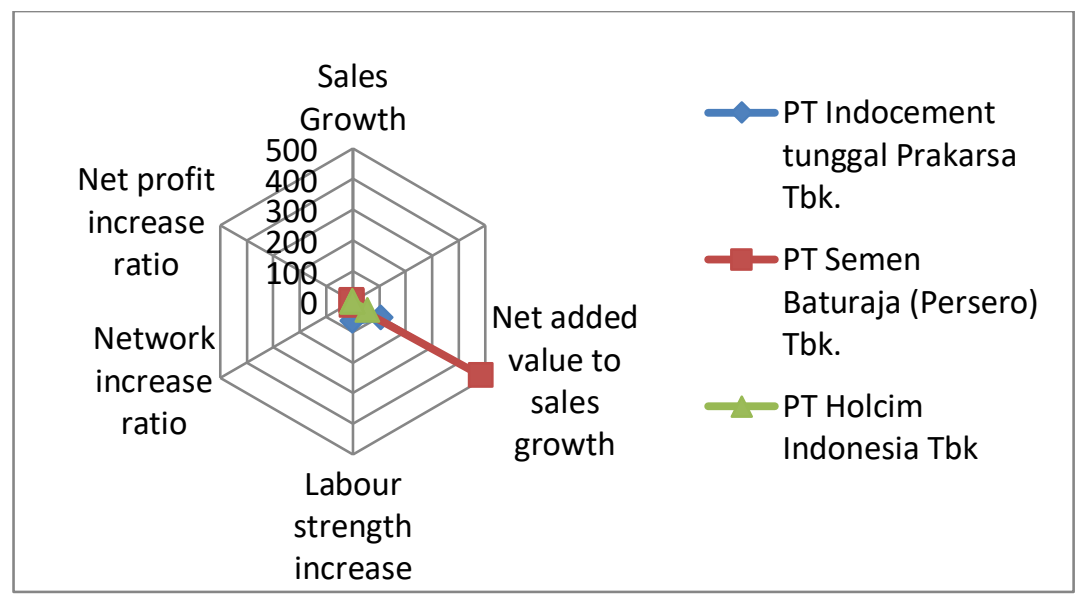

Gambar 13.

Grafik Rasio Potensi Pertumbuhan 2015

Tabel 14.

Rasio Potensi Pertumbuhan 2016

\begin{tabular}{cccc}
\hline $\begin{array}{c}\text { Rasio Potensi } \\
\text { Pertumbuhan 2016 }\end{array}$ & $\begin{array}{c}\text { PT Indocement } \\
\text { tunggal Prakarsa } \\
\text { Tbk }\end{array}$ & $\begin{array}{c}\text { PT Semen } \\
\text { Baturaja } \\
\text { (Persero) Tbk }\end{array}$ & $\begin{array}{c}\text { PT Holcim } \\
\text { Indonesia Tbk }\end{array}$ \\
\hline Sales Growth & 0.863 & 1.04 & 1.02 \\
\hline
\end{tabular}


Lanjutan

Tabel 14.

Rasio Potensi Pertumbuhan 2016

\begin{tabular}{cccc}
\hline $\begin{array}{c}\text { Rasio Potensi } \\
\text { Pertumbuhan 2016 }\end{array}$ & $\begin{array}{c}\text { PT Indocement } \\
\text { tunggal } \\
\text { Prakarsa Tbk }\end{array}$ & $\begin{array}{c}\text { PT Semen } \\
\text { Baturaja (Persero) } \\
\text { Tbk }\end{array}$ & $\begin{array}{c}\text { PT Holcim } \\
\text { Indonesia Tbk }\end{array}$ \\
\hline $\begin{array}{c}\text { Net added value to sales } \\
\text { growth }\end{array}$ & 97 & 612 & 5.7 \\
Labour strenght increase & 96 & 14 & 0.718 \\
Network increase ratio & 1.09 & 1.06 & 0.95 \\
Net profit increase ratio & 0.888 & 0.73 & 1.63 \\
\hline
\end{tabular}

\begin{tabular}{|l} 
Sales \\
Net added \\
value to \\
(Pales growth
\end{tabular}

Gambar 14.

Grafik Rasio Potensi Pertumbuhan 2016

Tabel 15.

Rasio Potensi Pertumbuhan 2017

\begin{tabular}{cccc}
\hline $\begin{array}{c}\text { Rasio Potensi } \\
\text { Pertumbuhan }\end{array}$ & $\begin{array}{c}\text { PT Indocement } \\
\text { tunggal Prakarsa Tbk }\end{array}$ & $\begin{array}{c}\text { PT Semen } \\
\text { Baturaja } \\
\text { (Persero) Tbk }\end{array}$ & $\begin{array}{c}\text { PT Holcim } \\
\text { Indonesia Tbk }\end{array}$ \\
\hline $\begin{array}{c}\text { Sales Growth } \\
\text { Net added value to sales } \\
\text { growth }\end{array}$ & 0.939 & 1.02 & 0.992 \\
Labour strenght increase & 92 & 579 & 61.4 \\
\hline
\end{tabular}


Lanjutan

Tabel 15.

Rasio Potensi Pertumbuhan 2017

\begin{tabular}{cccc}
\hline $\begin{array}{c}\text { Rasio Potensi } \\
\text { Pertumbuhan }\end{array}$ & $\begin{array}{c}\text { PT Indocement } \\
\text { tunggal Prakarsa } \\
\text { Tbk }\end{array}$ & $\begin{array}{c}\text { PT Semen } \\
\text { Baturaja } \\
\text { (Persero) Tbk }\end{array}$ & $\begin{array}{c}\text { PT Holcim } \\
\text { Indonesia Tbk }\end{array}$ \\
Network increase ratio & 0.939 & 1.09 & 0.891 \\
Net profit increase ratio & 0.939 & 0.57 & 2.6 \\
\hline
\end{tabular}

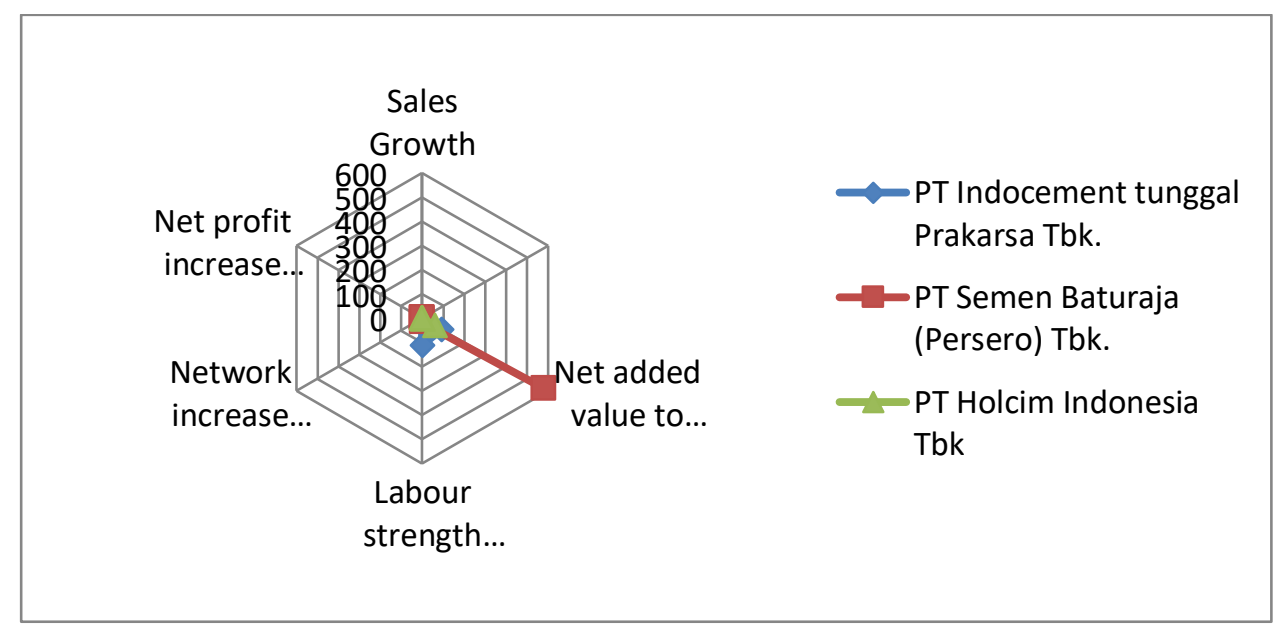

Gambar 15.

Grafik Rasio Potensi Pertumbuhan 2017

Analisa Rasio Potensi pertumbuhan. PT Semen Baturaja (Persero) Tbk pada tahun 2015, 2016 dan 2017 memiliki Sales Growth lebih tinggi yaitu 1.20, 1.04, 1.02. Sedangkan yang paling rendah pada tahun 2015,2016 dan 2017 adalah PT Indocement Tunggal Prakarsa Tbk yaitu 0.89, 0.863, 0.939. PT Semen Baturaja (Persero), Tbk memiliki Net Added Value to Sales Growth lebih besar pada tahun 2015,2016,2017 yaitu 485, 612, 579. Sedangkan PT. Wijaya Karya Beton Tbk memiliki Net Added Value to Sales Growth lebih kecil Pada tahun 2015, 2016 dan 2017 PT. Holcim Indonesia Tbk yaitu 0.974, 5.720, dan 61.4. PT.Indocement Tunggal Prakarsa, Tbk memiliki Labor Strengh Income lebih besar Pada tahun 
2015,2016,2017 Yaitu 64, 96, 112. dan yang paling kecil adalah PT Holcim Indonesia Tbk Pada tahun 2015, 2016 dan 2017 yaitu 0.565, 0.718 dan 1.43. PT Semen Baturaja (Persero) Tbk memiliki Networth Increase Ratio lebih tinggi pada tahun 2015 dan 2017 yaitu 1.10 dan 1.09. Pada tahun 2016 PT. Indocement Tunggal Prakarsa Tbk yaitu 1.09. Sedangkan PT Indocement Tunggal Prakarsa, Tbk Pada tahun 2015 memiliki Networth Increase Ratio paling kecil yaitu 0.971. pada tahun 2016 dan 2017 PT Holcim Indonesia Tbk paling rendah yaitu 0.95 dan 0.891. PT Semen Baturaja (Persero) Tbk pada tahun 2015 memiliki Net Profit Increase Ratio paling besar yaitu 1.05. Pada Tahun 2016 dan 2017 Paling besar PT Holcim Indonesia Tbk yaitu1.63 dan 2.6. Sedangkan Net Profit Increase Ratio yang paling rendah pada tahun 2015 PT Holcim Indonesia Tbk 0.265. Pada tahun 2016 dan 2017 PT Semen Baturaja (Persero) Tbk yaitu 0.73 dan 0.57.

\section{SIMPULAN}

Berdasarkan atas perbandingan kinerja menggunakan analisis radar pada PT Semen Baturaja (Persero) Tbk, PT Indocement Tunggal Prakarsa Tbk dan PT Holcim Indonesia Tbk. Hasil menunjukan bahwa dari analisa rasio profitabilitas PT Semen Baturaja (Persero) Tbk yang paling bagus dari beberapa perusahaan sejenis lainnya. Yang berarti PT Semen Baturaja (Persero) Tbk mampu menjalankan usahanya dalam memanfaatkan penjualan dengan laba bersih dan laba penjualan yang lebih maksimal. Berdasarkan rasio produktivitas PT Holcim Indonesia Tbk adalah yang terbaik. PT Holcim Indonesia Tbk mampu memanfaatkan tenaga kerja dalam aktivitas penjualannya. Pada rasio utilitas aktiva PT Indocement Tunggal 
Prakarsa Tbk adalah yang paling tinggi, dan memiliki kemampuan lebih besar dalam memanfaatkan total aktiva dalam menghasilkan penjualan. Dan pada rasio stabilitas PT Holcim Indonesia Tbk paling tinggi diantara beberapa perusahan sejenis. Yang berarti PT Holcim Indonesia Tbk mampu dalam melunasi hutang jangka panjangnya. Jika dilihat dari potensi pertumbuhan PT Semen Baturaja (Persero) Tbk memiliki potensi pertumbuhan paling bagus kecuali pada Net Increase Profit Ratio PT Semen Baturaja (Persero) Tbk yang paling kecil.

\section{REFERENSI}

Arfamaini, Rvi, (2017), Perbandingan analisis kinerja keuangan perusahaan yang terdaftar di BEI tahun 2013 dengan menggunakan Rasio-rasio dalam metode radar, Jurnal Manajemen Kinerja, 3, (2).

Ansari, Imn, (2018), Penggunaan metode Dupont dan radar dalam hubungan pengukuran kinerja keuangan setelah akuisisi ( Study Kasus PT Tifico Fiber Indonesia, Tbk ), Jurnal sekuritas, 1, (4), 132-151.

Fahmi, Irham. 2012. Analisis Laporan Keuangan. Bandung : CV Alfabeta.

Fahmi, Irham. 2014. Pengantar Perbankan Teori \& Aplikasi. Bandung: CV.Alfabeta.

Farid dan Siswanto. (2011). Analisis Laporan Keuangan. Jakarta: Bumi Aksara

Munawir. 2010. Analisis Laporan Keuangan. Edisi Keempat. Yogyakarta: Liberty.

Sutrisno. 2012. Manajemen Keuangan Teori, Konsep dan Aplikasi. Yogyakarta:

\section{EKONISIA.}

Sugiono, 2014. Metode Penelitian Pendidikan Pendekatan Kuantitatif, Kualitatif, dan R \&D Bandung : Alfabeta.

Setyawan, Roni, Bertuah, Eka dan Kurniasih, Yuliani., 2006. Kinerja Keuangan dengan Menggunakan Metode Radar pada Pusat Konservasi Tumbuhan Bogor, Uahawan (No.9).]

R Rachmawati Analisis Kinerja Perusahaan Menggunakan Metode Balance Scocecard Dengan Metode Radar (Studi pada Kasus pada PT. ANEKA JASA GRHADIKA GRESIK), Jurnal Manajemen dan Kewirausahaan, 2015. Volume 1 No. 19 